\title{
Morphological and functional evaluation of distal esophagus of rabbits submitted to esophageal infusion with caustic soda ${ }^{1}$
}

\section{Avaliações morfológica e funcional do esôfago distal de coelhos submetidos a infusão esofágica com soda cáustica}

\author{
Maria Aparecida Coelho de Arruda Henry', Carlos Eduardo Brossi Pelissari" ${ }^{\text {, }}$ Lídia Raquel Carvalho ${ }^{\text {III }}$ \\ I Full Professor, Department of Surgery and Orthopedy, School of Medicine, State University of São Paulo (UNESP), \\ Botucatu, São Paulo, Brazil. \\ II Assistant Professor, Department of Surgery, School of Medicine of Marilia, São Paulo, Brazil. \\ III Assistant Professor, Department of Statistics, Institute of Biosciences, UNESP, Botucatu, São Paulo, Brazil.
}

\begin{abstract}
The ingestion of caustic substances is an important emergency situation, because of its serious consequences. Purpose: To study morphological and functional alterations of the esophagus in rabbits submitted to esophageal infusion of caustic soda $(\mathrm{NaOH})$. Methods: The 88 rabbits studied were divided into 4 groups: $\mathrm{G}_{1}(\mathrm{n}=22)$ were submitted to esophageal infusion with distilled water. $\mathrm{G}_{2}, \mathrm{G}_{3}$, and $\mathrm{G}_{4}$ were submitted to esophageal infusion of $2 \%, 4 \%$ and $6 \% \mathrm{NaOH}$ respectively. Morphological alterations were studied in 12 animals from each group and manometric alterations in the remaining 10 . An analysis was made of lower esophageal sphincter (LES) pressure, number and amplitude of contractions in the distal third of the esophagus. These studies were performed before (moment M1) and at 30 minutes, 6 hours, and 24 hours after (moments M2, M3, and M4, respectively) esophageal infusion. Results: Morphological evaluation: G1 — no alterations; G2 - edema, hyperemia, and ecdysis; G3 - enlarged calibre of esophagus, ulcers, ecdysis of mucosa; G4 — lesions similar to G3, but more intense, areas of extensive hemorrhage at M3 and M4. Functional evaluation: LES was higher at M2; the number of distal third lower esophageal contractions in G3, and G4 was lower; and the contraction amplitude was lower in G4. Conclusions: 1) Esophageal infusion with caustic soda in rabbits is a good experimental model for studying caustic esophagites. 2) Esophageal infusion with $\mathrm{NaOH}$ caused lesions in the esophageal wall, with gravity proportional to solution concentration; 3) Infusion caused LES spasm at M2, and reduced both contraction number and amplitude in the distal third of the esophagus.
\end{abstract}

Key words: Sodium Hydroxide. Esophagus. Morphology. Evaluation Studies. Rabbits.

\section{RESUMO}

A ingestão de substâncias cáusticas constitui importante situação de emergência, tendo em vista a gravidade de suas seqüelas. Objetivo: Estudar as alterações morfológicas e funcionais do esôfago de coelhos submetidos à infusão esofágica com soda cáustica $(\mathrm{NaOH})$. Métodos: 88 coelhos foram divididos em 4 grupos: $\mathrm{G} 1(\mathrm{n}=22)$ foi submetido à infusão esofágica com água destilada; G2, G3 e G4 foram submetidos a infusão esofágica com $\mathrm{NaOH}$ a 2\%, 4\% e $6 \%$, respectivamente. Alterações morfológicas foram estudadas em 12 animais de cada grupo e as alterações manométricas, nos 10 animais restantes. Foram feitas análises do esfíncter inferior do esôfago (EIE), número e amplitude das contrações no terço distal do esôfago. Estes estudos foram realizados antes (momento $1-\mathrm{M} 1$ ) e aos 30 minutos, 6 horas e 24 horas após a infusão esofágica (momentos M2, M3 e M4, respectivamente). Resultados: Avaliação macroscópica: G1 — sem alterações; G2 — edema, hiperemia e descamação; G3 — aumento do calibre do esôfago, úlceras, descamação da mucosa; G4 — lesões semelhantes as do G3, porém mais intensas, áreas de extensa hemorragia. Avaliação funcional: a pressão no EIE foi mais elevada em M2 no grupo 2; o número das contrações no terço distal do esôfago foi menor em G3 e G4, e a amplitude das contrações foi menor em G4. Conclusões: 1) a infusão esofágica com $\mathrm{NaOH}$ constitui excelente modelo experimental de esofagite cáustica no coelho; 2) a infusão esofágica com $\mathrm{NaOH}$ causa lesões na parede do esôfago, com gravidade proporcional a concentração da solução; 3) a infusão causou espasmo do EIE em M2 e redução do número e amplitude das contrações no terço distal do esôfago.

Descritores: Hidróxido de Sódio. Esôfago. Morfologia. Estudos de Avaliação. Coelhos.

1. Research performed at Experimental Surgery Laboratory, Department of Surgery and Orthopedy, School of Medicine, State University of São Paulo (UNESP), Botucatu, São Paulo, Brazil. 


\section{Introduction}

Ingestion of caustic substances is an important emergency situation with important sequelae. These type of lesions have been described for many years, since the industrial revolution produced various commercial chemical agents, disinfectants, bleaches, and domestic cleaning products ${ }^{1}$.

Most patients with these lesions are children, with accidental ingestion of the lesive agent in a domestic environment ${ }^{2,3}$. In adults, although accidental ingestion does occur, the predominance is attempted suicide ${ }^{4}$.

The most common substances causing these lesions are the alkalines, predominantly sodium hydroxide, potassium carbonate, calcium oxide, and sodium peroxide ${ }^{5}$. In our country, the most common product is caustic soda, either pure or in products used for cleaning sinks and pipes, and in the rural zone for domestic fabrication of soaps ${ }^{5}$.

The esophagus is the most commonly damaged organ from ingestion of caustic substances ${ }^{6,7}$, followed by the stomach $^{8}$; the airways ${ }^{9,10}$ can also be compromised. The seriousness of these lesions depends on various factors; substance volume and concentration are the most important, along with contact time with the esophageal mucous.

Several authors have conducted esophagus motor activity studies on patients who have ingested caustic substances ${ }^{11,12,13,14}$; they have found serious disorders in those with serious lesions in the acute phase.

The objective of this work is to study manometric and morphological changes of the esophagus in rabbits submitted to esophagic infusion with caustic soda $(\mathrm{NaOH})$.

\section{Methods}

88 albino Norfolk rabbits weighing between 1,800 and 2,300g were studied.

Research was initiated after project approval from our institution's Animal Research Ethics Commission.

Animals were studied at four different moments:

Moment 1 - M1 - before esophageal infusion with $\mathrm{NaOH}$

Moment 2 - M2 - 30 minutes after infusion

Moment 3 - M3 - 6 hours after infusion

Moment 4 - M4 - 24 hours after infusion

Rabbits were divided into 4 groups of 22 animals each for different concentrations of $\mathrm{NaOH}$.

Group 1-G1 - control distilled water.

Group 2- G2 - 2\% NaOH

Group 3-G3 - 4\% NaOH

Group 4-G4 - 6\% NaOH

Distilled water and $\mathrm{NaOH}$ were infused at the transition point between the mid and distal thirds of the esophagus. A number 8 Levine catheter was used to infuse $1.5 \mathrm{ml}$ solution over 5 to 7 seconds with the rabbit inclined at $30^{\circ}$ in relation to the study bench.

Esophageal manometry was performed in 10 animals from each group; they were then euthanized and macroscopically studied after M4. The other 12 animals in each group were sacrificed after each infusion time; four animals per group at M1, M2, M3, and M4. The esophagus were removed for macroscopic and microscopic anatomicalmorphological exams. Euthanasia was induced with endovenous sodium pentobarbital ( $50 \mathrm{mg} / \mathrm{kg}$ weight). The same anaesthetic was used in esophageal manometry and infusion at $30 \mathrm{mg} / \mathrm{kg}$ weight.

The esophageal electromanometric study was performed using the intermittent catheter pulling technique, standardized in our laboratory ${ }^{15,16,17,18,19}$. The catheter was introduced as far as the stomach and was them pulled back in half centimetre steps until it reached the pharynx thus allowing study of the lower esophageal sphincter and body of the esophagus.

Lower esophageal sphincter (LES) pressure and the number and amplitude of contractions in the distal third of the esophagus were measured at each experimental moment.

Profile analysis ${ }^{20}$ was used for variables with normal distribution, and the Freedman and KruskalWallis tests for variables which did not present normal distribution ${ }^{21}$.

\section{Results}

\section{Morphological evaluation}

1.1. Macroscopy

Group 1 - No evidence of morphological

alterations.

Group 2 - No alterations were seen in the pleural cavities and abdomen during esophageal withdrawl. The esophagus presented diffuse edema, more evident in the distal portions and at M3 and M4. At M2 the longitudinal opening of the esophagus showed diffuse epithelial ecdysis and moderate hyperemia. At M3 and M4 fibrin plaques were seen adhering and building up on the wall.

Group 3 - There was intense diffuse edema of the esophagus. Opening of the esophagus showed more extensive and deep ecdysis, causing hemorrhagic ulcers at M2 and fibrinous ulcers at M3 and M4 (Figure 1).

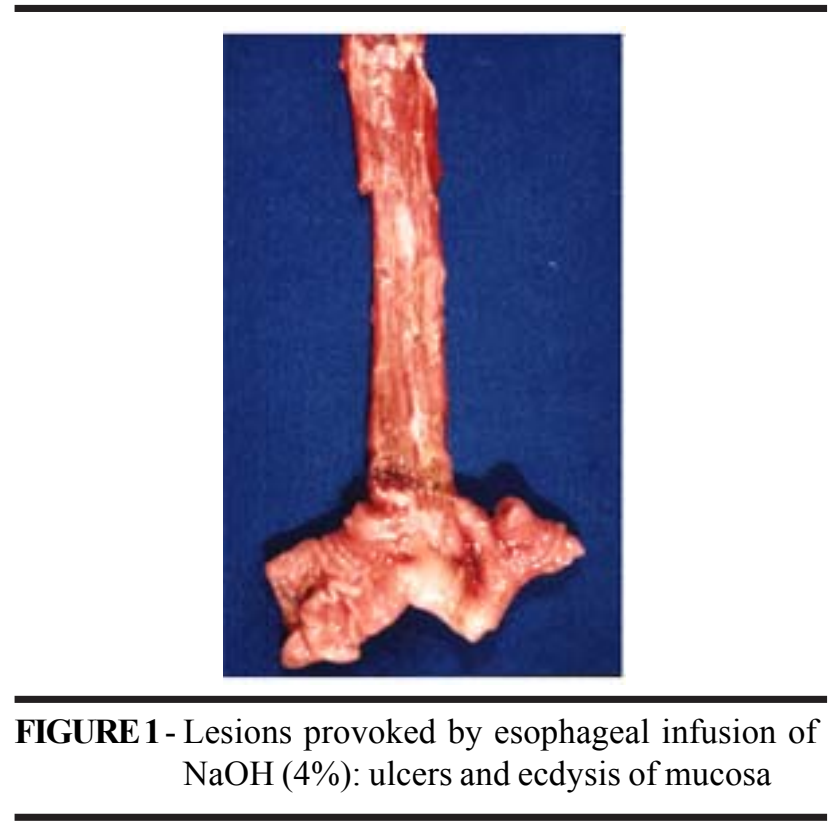


Group 4 - Six animals in this group showed hemorrhagic foci in the pulmonary parenchyma and pleural hemorrhage (M2, M3, and M4). Longitudinal opening of the esophagus showed large areas of epithelial necrosis, hemorrhagic foci, and hemorrhagic ulcers at M2. These lesions were more intense at M3 and M4 (Figure 2).

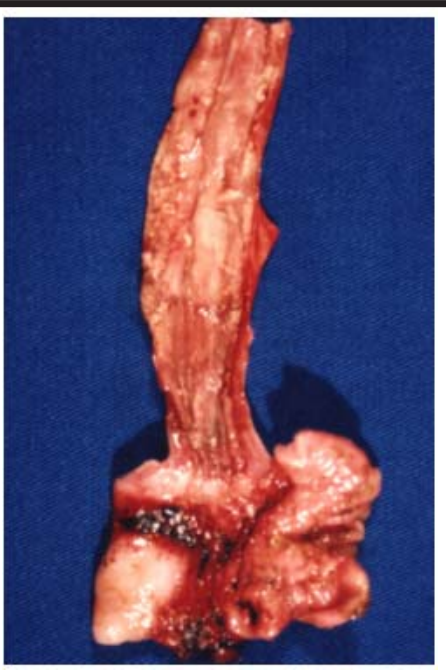

FIGURE 2 - Areas of extensive hemorrhage provoked by esophageal infusion of $\mathrm{NaOH}(6 \%)$

\subsection{Microscopy}

Group 1 - No abnormalities were seen in the microscopic examination.

Group 2 - There were incomplete lesion points in the epithelium, varying from superficial to moderate. At M2 the deep structures were preserved, however there was extensive epithelial liquefaction.

At M3, there was also neutrophylic inflammatory process and edema, which extended to the submucosa. At M4, this lesion reached the muscle where there were areas of coagulation.

Group 3 - The lesions in this group were more intense and extensive, with epithelial loss, exposing the deeper layers (M2). At M3 and M4 these lesions were accompanied by large edema and neutrophylic inflammation, and in some areas purulent fibrin (Figure 3).

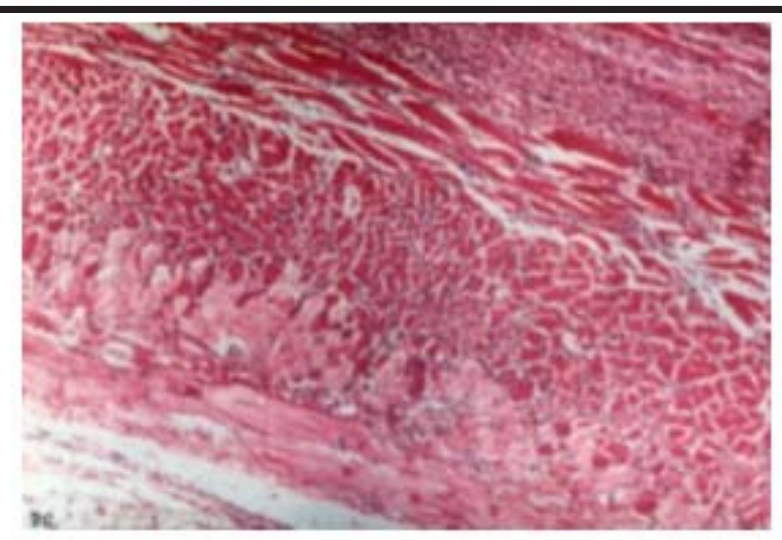

FIGURE 3 - Microscopic view of esophageal mucosa: edema and neutrophylic inflammation $(\mathrm{NaOH}$ solution $4 \%$ )
Group 4 - These animals had similar alterations to the previous group, however with more intense and deep inflammation and liquefaction. Many vessels presented dilation or thrombosis. There was adventitial edema, hemorrhage, and inflammatory process (M3 and M4) (Figure 4).

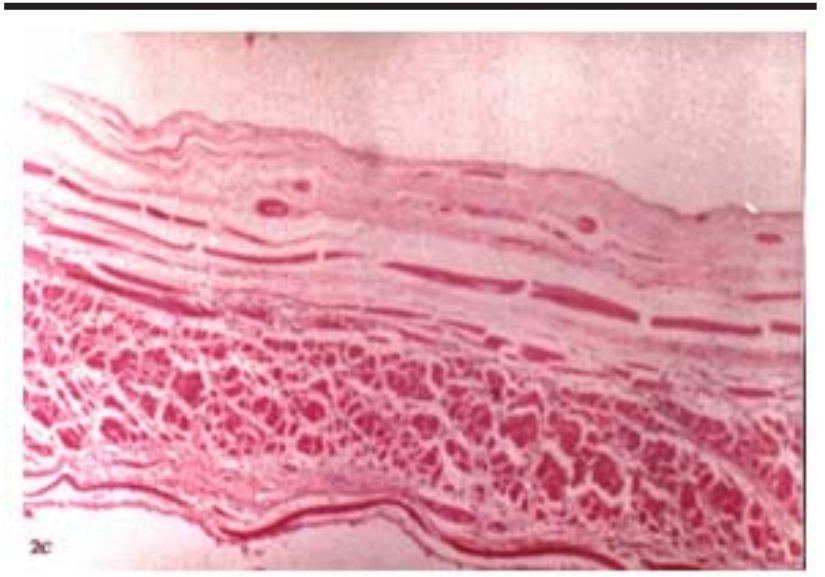

FIGURE4-Adventitial edema, hemorrhage and inflammatory process provoked by esophageal infusion of $\mathrm{NaOH}$ solution $(6 \%)$

\section{Functional evaluation}

\subsection{LES pressure $(\mathrm{mmHg})$}

Table 1 shows the mean and standard deviation values of LES pressure in the four groups and four moments of the study.

TABLE 1 - Mean and SD values of LES pressure LES $(\mathrm{mmHg})$ in the four groups at four moments

\begin{tabular}{|c|c|c|c|c|}
\hline \multicolumn{2}{|c|}{ Group } & \multicolumn{2}{|c|}{ Moments } & \multirow[b]{2}{*}{ M4 } \\
\hline & M1 & M2 & M3 & \\
\hline 1 & $35.7 \pm 7.6 \mathrm{a}$ & $35.4 \pm 7.9 \mathrm{a}$ & $31.0 \pm 11.6 \mathrm{a}$ & $25.8 \pm 9.1 \mathrm{a}$ \\
\hline 2 & $26.9 \pm 10.6 b$ & $43.0 \pm 12.1 \mathrm{a}$ & $31.2 \pm 7.7 \mathrm{ab}$ & $37.4 \pm 20.4 \mathrm{ab}$ \\
\hline 3 & $34.1 \pm 10.6 \mathrm{a}$ & $40.4 \pm 11.5 \mathrm{a}$ & $37.4 \pm 9.5 \mathrm{a}$ & $28.2 \pm 10.3 \mathrm{a}$ \\
\hline 4 & $30.7 \pm 10.0 \mathrm{a}$ & $33.3 \pm 7.2 \mathrm{a}$ & $39.0 \pm 13.1 \mathrm{a}$ & $38.8 \pm 10.9 \mathrm{a}$ \\
\hline
\end{tabular}

Note: Significant differences among groups into each moment, were pointed out by small different letters.

There were no statistical differences between groups. Values were significantly higher at M2 in group $2(\mathrm{p}<0.005)$.

2.2. Number of contractions in the distal third of the esophagus (Table 2). 
TABLE 2 - Mean and SD values of number of contractions in the four groups at four moments

\begin{tabular}{ccccc}
\hline Group & \multicolumn{4}{c}{ Moments } \\
\hline & M1 & M2 & M3 & M4 \\
& & & & \\
$\mathbf{1}$ & $5.8 \pm 5.9 \mathrm{a}$ & $6.1 \pm 5.5 \mathrm{a}$ & $4.2 \pm 5.5 \mathrm{a}$ & $7.9 \pm 4.9 \mathrm{a}$ \\
& $\mathrm{A}$ & $\mathrm{A}$ & $\mathrm{A}$ & $\mathrm{A}$ \\
$\mathbf{2}$ & $4.6 \pm 2.4 \mathrm{ab}$ & $7.5 \pm 2.6 \mathrm{a}$ & $3.1 \pm 2.0 \mathrm{c}$ & $4.8 \pm 1.9 \mathrm{bc}$ \\
& $\mathrm{A}$ & $\mathrm{A}$ & $\mathrm{A}$ & $\mathrm{AB}$ \\
$\mathbf{3}$ & $5.6 \pm 4.4 \mathrm{a}$ & $7.7 \pm 3.2 \mathrm{a}$ & $1.2 \pm 0.8 \mathrm{a}$ & $3.7 \pm 2.0 \mathrm{a}$ \\
& $\mathrm{A}$ & $\mathrm{A}$ & $\mathrm{A}$ & $\mathrm{B}$ \\
$\mathbf{4}$ & $4.5 \pm 3.3 \mathrm{a}$ & $4.9 \pm 3.8 \mathrm{a}$ & $3.5 \pm 3.9 \mathrm{a}$ & $3.9 \pm 2.4 \mathrm{a}$ \\
& $\mathrm{A}$ & $\mathrm{A}$ & $\mathrm{A}$ & $\mathrm{B}$ \\
\hline
\end{tabular}

Note: Small letters - comparison of means of the moments into each group. Capital letters - comparison of means of the groups into each moment.

The number of distal esophagic contractions measured at M4 was significantly reduced in Groups 3, and $4(4 \%$ and $6 \% \mathrm{NaOH}$ esophageal infusion respectively).

2.3. Contraction amplitude $(\mathrm{mmHg})$ in the distal third of the esophagus (Table 3 )

TABLE 3 - Mean and SD values of esophageal distal third contraction amplitude ( $\mathrm{mmHg}$ ) in the four groups at four moments

\begin{tabular}{lccccc}
\hline Group & \multicolumn{5}{c}{ Moments } \\
\hline & M1 & M2 & M3 & M4 & Group \\
$\mathbf{1}$ & $14.6 \pm 6.7$ & $20.1 \pm 8.1$ & $18.5 \pm 8.4$ & $19.1 \pm 7.7$ & $18.1 \pm 7.7 \mathrm{AB}$ \\
$\mathbf{2}$ & $16.8 \pm 5.1$ & $15.7 \pm 1.5$ & $18.3 \pm 5.5$ & $14.9 \pm 4.6$ & $16.4 \pm 4.5 \mathrm{AB}$ \\
$\mathbf{3}$ & $18.8 \pm 5.6$ & $21.1 \pm 6.8$ & $18.4 \pm 6.9$ & $21.6 \pm 9.8$ & $20.1 \pm 7.3 \mathrm{~A}$ \\
$\mathbf{4}$ & $13.6 \pm 6.6$ & $13.7 \pm 6.4$ & $15.8 \pm 2.2$ & $12.9 \pm 5.8$ & $14.0 \pm 5.4 \mathrm{~B}$
\end{tabular}

Note: Capital letters - comparison of the means of the groups.

There was no significant difference among experimental moments; however values for Group 4 animals $(6 \% \mathrm{NaOH})$ were significantly reduced.

\section{Discussion}

The objective of this work was to study morphological and functional alterations caused by experimentally induced esophagitis using caustic soda, the most common etiological agent in caustic esophagitis ${ }^{22}$.

Various experimental models of caustic esophagitis have been developed using the $\operatorname{dog}^{23}$, cat $^{24}$, rabbit ${ }^{25}$, and rat $^{26}$.
We chose the rabbit for this study because of its availability and ease of manipulation as seen in other works from our laboratory ${ }^{27,18,19}$. Only male rabbits were used, as various authors have reported female hormones affecting lower esophageal sphincter pressure ${ }^{28,29}$.

Caustic esophagitis can be induced in various ways, the most common being product topical application ${ }^{30}$ and esophagic infusion ${ }^{26}$. We opted for infusing solution in the esophagic lumen, because it is closer to what occurs in clinical practice. Animals were positioned in $30^{\circ}$ (proclive) inclination during infusion, in an attempt to avoid respiratory complications caused by solution reflux. Animals were anaesthetized during this process as it is painful.

The esophagus in Group 2 animals (2\% $\mathrm{NaOH}$ ) presented moderate hyperemia and a small increase in calibre 6 and 24 hours after infusion, slight alterations characterized as Grade 1 lesions ${ }^{22}$.

Esophageal infusion with higher $\mathrm{NaOH}$ concentrations (4 and 6\%) caused more intense and diffuse lesions, with ulcers and large areas of necrosis, more serious at M3 and M4. These are compatible with the Grade 2 and 3 classifications from Artigas and Brandão ${ }^{22}$.

Increased concentrations of caustic soda clearly caused more serious lesions ${ }^{25}$. The morphological study also showed increasing seriousness of the lesions over time, due to caustic soda residue remaining on the esophageal wall continuing its lesive action ${ }^{31}$.

Functional evaluation of the esophagus showed much higher LES pressures at M2 in group 2, and this could be explained by lower esophageal sphincter spasm which occurred after $\mathrm{NaOH}$ infusion. This spasm can protect the digestive tract distal to the esophagus, but at the same time can make esophageal drainage more difficult, with more caustic residue remaining on the esophageal wall, with more serious lesions.

Esophageal manometry showed a significant reduction in number of distal esophagus contractions at M4 in animals submitted to 4 and $6 \% \mathrm{NaOH}$ concentration infusions. These alterations could be related to clinical findings in literature ${ }^{14,32}$. According to these authors patients who ingest caustic soda present hypotensive esophageal contractions and aperistalsis.

Rabbits submitted to $6 \% \mathrm{NaOH}$ esophageal infusion had significantly reduced contraction amplitude in the distal esophagus. This motor disorder could be explained by plexus nerve lesion provoked by high concentration $\mathrm{NaOH}$ solution. However further study is required to confirm this hypothesis.

\section{Conclusions}

1. Esophageal infusion of caustic soda in rabbits is an adequate experimental model for studying caustic esophagitis.

2. Esophageal infusion with caustic soda caused lesions in the esophageal wall; lesion gravity was directly proportional to solution concentration.

3. Esophageal infusion of caustic soda caused spasm of the lower esophageal sphincter. 
4. Motor disorders represented by reduced number of distal esophageal contractions were seen after esophageal infusion of caustic soda, in $4 \%$ and $6 \% \mathrm{NaOH}$ solutions.

5. Motor disorders represented by reduced amplitude of distal esophageal contractions were seen after esophageal infusion of caustic soda ( $6 \%$ solution).

\section{References}

1.Belsey R. Corrosive strictures of the esophagus. Arq Bras Cir Dig. 1993;8(4):107-14.

2.Garcin M; Brisac A, Jouglard J. Les ésophagites caustiques de l'enfant. J Fr Otorhinolaryngol. 1981;30(9):555-64.

3.Symbas PN, Vlasis SE, Hatcher CRJ. Esophagitis secondary to ingestion of caustic material. Ann Thorac Surg. 1983;36(1):73-7.

4.Mamede RCM, Mello Filho FV. Treatment of caustic ingestion: an analysis of 239 cases. Dis Esophagus. 2002;15:210-3.

5.Rigo GP, Camellini L, Guazzetti S, Bedogni G, Merighi A, Bellis L, Scarcelli A, Manenti F. What is the utility of selected clinical and endoscopic parameters in predicting the risk of death after caustic ingestion? Endoscopy. 2002;34:304-10.

6.Andreoni B, Farina ML, Biffi R, Crosta C. Esophageal perforation and caustic injury: emergency management of caustic ingestion. Dis Esophagus. 1997;10:95-100.

7.Henry MACA, Lerco MM, Oliveira WK, Batalha PKM. Esophageal lesions caused by ingestion of caustic or corrosive agents. Arq Bras Cir Dig. 2005;18(1): 3-7.

8.Viana AT. Estenose antro-pilórica por cáusticos ou corrosivos. Acta Cir Bras. 1988;3(3):95-102.

9. Chandramohan SM, Kanagavel M. Rathinam S. Pharingoesophagogastric corrosive strictures: dilemmes in management: to eat or to speach? Experience with 35 patients. Dis Esophagus. 2004; 17 Suppl 1:A 66.

10.Saelti R, Silvestrini M, Cutrone C, Barion V, Mirri L, Narne $\mathrm{S}$. Endoscopic treatment of upper airway and digestive tract lesions caused by caustic agents. Ann Otol Rhinol Laringol. 2003;112:29-36.

11.Moody FG, Garret JM.Esophageal achalasia following lye ingestion. Ann Surg. 1969;170:775-84.

12.Rezende JM, Leite ANG, Araújo GM, Montalvão F. Estudo manométrico da motilidade esofagiana na estenose cáustica do esôfago. Rev. Goiana Med. 1976;22:67-75.

13.Ortiz Escandel A, Haro LFM, Parrilla PP, Castellanos EG, Soria CT, Romero ME, Albasani JLA. Produce da ingesta de cáusticos alteraciones motoras esofágicas irreversibles? Estudio manometrico de 17 casos. Rev Esp Enferm Apar Dig. 1989;75(6):553-6.

14.Dantas RO, Mamede RCM. Esophageal motility in patients with esophageal caustic injury. Am J Gastroenterol. 1996;91(6):1157-61.

15.Henry MACA, Vercesi LAP. Junção gastroesofágica no cão: comprimento da zona de alta pressão e estudo pHmétrico. Rev Hosp Clin Fac Med São Paulo. 1980;35:225-7.

16.Bretan O, Henry MACA. Electromanometric study of the esophageal sphincters and their correlation. Acta Cir Bras. 1996;11(1):8-10.

17.Tagliarini JV, Henry MACA, Bretan O. Eletromanometria do esfincter superior do esôfago antes e após perfusão esofágica com ácido clorídrico $0,1 \mathrm{~N}$ : estudo experimental no cão. Arq Gastroenterol. 2001;38(3):189-93.

18.Henry MACA, Motta DCP, Silva RA. Manometric evaluation of distal esophagus of rabbits submitted to open and laparoscopic fundoplication. Arq Gastroenterol. 2002;39(2):106-10.

19.Oliveira WK, Henry MACA, Lerco MM. Manometric evaluation of lower esophageal sphincter of rabbits submitted to total and partial fundoplication. Acta Cir Bras. 2004;19(5):555-64.

20.Morrison DF. Multivariate statiscal methods. New York: Mc Graw Hill; 1967.338 p.

21.Fisher LD, Van Belle G. Biostatistics: methodogy for the healt sciences. New York: Wiley-interscience; 1993. 991 p.

22.Liu A Jr, Richardson MA. Effects of n-acetylcystine on experimentally induced esophageal lye injury. Ann Otol Rhinol Laryngol. 1985;94:477-82.

23.Butler C, Madden J W, Davis WM, Peacock EE Jr. Morphologic aspects of experimental esophageal lye strictures. II Effect of steroid hormones, bougienage, and induced lathyrism on acute lye burns. Surgery. 1977;81(4):431-5.

24. Maves MD, Carithers GS, Birak HG. Esophageal burns secondary to disc battery ingestion. Ann Otol Rhinol Laryngol. 1984;93:364-9.

25.Krey H. On the treatment of corrosive lesions in the esophagus: an experimental study. Acta Otolaryngol. 1952;102:1-68.

26.Bingol-Koluglu M, Tanyel FC, Muftüoglu S, Renda N, Çakar N, Büyükpamukçu N, Hiçsonmez A. The preventive effect of heparin on stricture formation after caustic esophageal burns. J Pediatr Surg. 1999;34(2):291-4. 
27.Uvo SAB, Henry MACA. Efeito da laringectomia horizontal associada ou não a esvaziamento cervical e glossectomia total sobre o esfíncter superior do esôfago: estudo experimental no coelho. Acta Cir Bras. 1993;8(1):114.

28. Vanthiel DH, Gavaler JS, Stremple J. Lower esophageal sphincter pressure in women using sequential oral contraceptives. Gastroenterology. 1976;71(2):232-4.

29. Vanthiel DH, Gavaler JS, Joshi SN; Sara RK, Stremple J. Heartburn of pregnancy. Gastroenterology. 1977;72(4):666-8.

30.Ashcroft KW, Padula RT. The effect of dilute corrosives on the esophagus. Pediatrics. 1974;53(2):226-32.

31.Kirsh MM, Ritter F. Caustic ingestion and subsequent damage to the oropharingeal and digestive passages. Ann Thorac Surg. 1976;21(1):74-82.

32.Rezende JM, Leite ANG, Araújo GM, Montalvão F. Estudo manométrico da motilidade esofagiana na estenose cáustica do esôfago. Rev Goiana Méd. 1976;22:67-75.

\section{Correpondence:}

Conflict of interest: none Maria Aparecida Coelho de Arruda Henry

Rua Miguel Cioffi, 200

Financial source: none

18607-790 Botucatu - São Paulo Brazil

Received: July 11, 2007

rhenry@ibb.unesp.br

Review: September 12, 2007

Accepted: October 16, 2007

\section{How to cite this article}

Henry MACA, Pelissari CEB, Carvalho LR. Morphological and functional evaluation of distal esophagus of rabbits submitted to esophageal infusion with caustic soda. Acta Cir Bras. [serial on the Internet] 2008 Jan-Feb;23(1). Available from URL: http://www.scielo.br/acb 